\title{
Use of mechanistic-empirical method of pavement design for performance sensitivity analysis to asphalt pavement fatigue
}

\author{
Sensibilidade do desempenho à fadiga de \\ revestimentos asfálticos compostos por ligante polimérico
}

\author{
Natalia Assunção Brasil Silva ${ }^{1}$, Taciano Oliveira da Silva ${ }^{2}$ \\ Heraldo Nunes Pitanga ${ }^{3}$, Geraldo Luciano de Oliveira Marques ${ }^{3}$
}

\footnotetext{
${ }^{1}$ Universidade Federal de São João del-Rei, Campus Alto Paraopeba (CAP), Rodovia: MG 443, km-7, s/n, CEP: 36420000, Ouro Branco, Minas Gerais, Brazil.

${ }^{2}$ Universidade Federal de Viçosa, Departamento de Engenharia Civil, Av. Peter Henry Rolfs, s/n, CEP: 36570-900, Viçosa, Minas Gerais, Brazil.

${ }^{3}$ Universidade Federal de Juiz de Fora, Campus Universitário, Departamento de Transportes e Geotecnia, Rua José Lourenço Kelmer, s/n, CEP: 36036-900, Juiz de Fora, Minas Gerais, Brazil.

e-mail: natalia.brasil@ufob.edu.br, taciano.silva@ufv.br, geraldo.marques@ufjf.edu.br; heraldo.pitanga@ufv.br
}

\begin{abstract}
There are several factors (geometric, mechanical and loading) that can influence the design of the flexible pavement and its performance regarding the appearance of fatigue cracks. Therefore, the mechanisticempirical methods for design are widely accepted and used in the field of paving engineering. However, for mechanistic analysis there is a range of fatigue models that can provide different pavement design. This study aimed to analyze the performance sensitivity to asphalt layer fatigue according to data derived from a mechanistic-empirical design of the pavement and considering different fatigue models. The following variables were considered in the fatigue models: the mechanical properties of the structural materials, the thicknesses of the structural layers and the load applied to the structure. The asphalt design mixtures contemplated in the research were defined according to the Marshall mixing design method, framed in two granulometric ranges applicable to asphalt concrete with polymeric binder. The mechanistic-empirical protocol involved the pre-design of pavement structures using the empirical method of the National Department of Transport Infrastructure (DNIT) and its mechanistic analysis using the computer program Elsym5, which considers that horizontal layers are formed by elastic-linear and isotropic materials. The results showed that fatigue performance and surface course layer design varied according to fatigue models applied in different scenarios. However, the sensitivity of performance to surface course fatigue determined by these models, given the variations of the factors studied, was approximately the same. Thus, it was concluded that the fatigue of surface course was more sensitive to the variation of the thickness of the surface course layer than to the variation of the applied load value, followed by the soil resilience module of the subgrade.
\end{abstract}

Keywords: SBS-modified asphalt mixtures, mechanistic-empirical analysis, fatigue models.

\section{RESUMO}

São vários os fatores (geométricos, mecânicos e de carregamento) que podem influenciar no dimensionamento do pavimento flexível e no seu desempenho quanto ao aparecimento de fissuras por fadiga. Por isso, os métodos mecanístico-empíricos para o dimensionamento são amplamente aceitos e utilizados no âmbito da engenharia de pavimentação. Entretanto, para a análise mecanística existe uma gama de modelos de fadiga que podem proporcionar diferentes dimensionamentos do pavimento. Este estudo visou analisar a sensibilidade do desempenho à fadiga do revestimento asfáltico de acordo com dados derivados de um dimensionamento mecanístico-empírico do pavimento e levando em consideração diferentes modelos de fadiga. As seguintes variáveis foram consideradas nos modelos de fadiga: as propriedades mecânicas dos 
materiais estruturais, as espessuras das camadas estruturais e a carga aplicada à estrutura. As misturas asfálticas de projeto contempladas na pesquisa foram definidas de acordo com o método de projeto de mistura Marshall, enquadradas em duas distintas faixas granulométricas aplicáveis ao concreto asfáltico com ligante polimérico. O protocolo mecanístico-empírico envolveu o pré-projeto das estruturas do pavimento utilizando o método empírico do Departamento Nacional de Infraestrutura de Transportes (DNIT) e sua análise mecanística utilizando o programa de computador Elsym5, o qual considera que as camadas horizontais são formadas por materiais elástico-lineares e isotrópicos. Os resultados mostraram que o desempenho à fadiga e o dimensionamento da camada de revestimento asfáltico variaram conforme os modelos de fadiga aplicados nos diferentes cenários. Porém, a sensibilidade do desempenho à fadiga do revestimento asfáltico determinado por esses modelos, diante das variações dos fatores estudados, foi aproximadamente a mesma. Assim, concluiu-se que a fadiga dos revestimentos asfálticos foi mais sensível à variação da espessura da camada de revestimento asfáltico do que à variação do valor de carga aplicada, seguidas do módulo de resiliência do solo do subleito.

Palavras-chave: Misturas asfálticas modificadas com polímero SBS. Análise mecanístico-empírica do pavimento. Modelos de desempenho à fadiga do pavimento.

\section{INTRODUCTION}

Fatigue cracking of surface course is among the main of distress mechanisms of the pavement [1]. This defect consists of a progressive degradation of the material properties due to the application of cyclic stresses which value is lower than the material resistance [1]. It is typically caused by elastic strains derived from traffic load repetitions, which leads to failure of the surface course [2]. As each of these layers plays a particular role in the pavement structure and is comprised by a specific type of material, it is necessary to consider their respective elastic stiffness and thicknesses in the distribution of stresses and strains within the pavement.

In Brazil, pavements have often been designed using empirical design method prescribed by the National Department of Transport Infrastructure - DNIT [3], based on the CBR test, on design curves developed by the United States Army Corps of Engineers (USACE) and on data obtained from the American Association of State Highway and Transportation Officials (AASHTO) Road Test in the late 1950s , adapted by engineer Murillo Lopes de Souza [4]. However, numerous variables can influence an empirical analysis, including traffic characteristics, parameters related to climatic factors and structural responses of the pavement (stresses and strains). Thus, the results derived from empirical methods do not always coincide with the conditions found in the field [5].

Therefore, the mechanistic-empirical method has been increasingly used for pavement design [2]. In the United States, Canada and some South American countries, the pavement are designed by the MechanistEmpirical Pavement Design Guide (MEPDG) developed by AASHTO [5]. In Brazil, the new method of pavement design of DNIT [National Pavement Dimensioning Method (MeDiNa)] is in the implementation phase, which presents an mechanistic-empirical approach in the analysis of the structure of the pavements [6]. MeDiNa considers in design the stresses, strains and displacements of the layer system in relation to the applied loading, in addition to characteristics of the structural materials used, obtained in laboratory tests.

Different fatigue models are referenced in the literature and in software that allow an overview of the mechanical response of the pavement structure when subjected to traffic loads. These may include studies from PINTO [7], DNER [8], FHWA [9] and FRANCO [10]. However, it appears that each fatigue performance model of the surface course has its specific issues, which can be based on the composition of asphalt mixtures, on the condition of the fatigue test or the calibration of the model obtained in the laboratory.

Thus, in the light of the importance of mechanistic-empirical methods to the design of asphalt pavements and the need for applying fatigue models, it should be noted that the availability (or possible application) of different models can provide different layer thicknesses during the pavement design process. In addition, it should also be noted that variations in the resilient moduli of the subgrade soil and the surface course, and the load to which the structure is subjected can also play a role in the pavement performance and, consequently, in its service life.

Considering the above observations, this study aims to identify which components are most influential in the fatigue performance of the surface course of an asphalt pavement. In other words, this study aimed to analyze the performance sensitivity to asphalt layer fatigue according to data derived from a mechanisticempirical pavement design method and taking into account different fatigue models. In this analysis, different structures were used, with variations in surface course thicknesses, load applied in the structure and 
mechanical properties of the subgrade and surface course layers.

In the technical-scientific literature on the subject, it is observed that research has analyzed the sensitivity of flexible pavements dimensioned by MEPDG in view of the effects of the variation of surface course thickness, base and subbase on the development of fatigue cracks [11, 12]. Other studies evaluated performance prediction models for fatigue rupture in cement treated gravel base layer (BGTC) [13]. However, it is identified the absence of studies that analyze the implications, on the dimensioning of asphalt pavements, resulting from the adoption of different fatigue models and the consideration of the possible additional influence of geometric variables (thickness), mechanics (engineering properties of structural materials) and loading (axle load) in the mechanistic-empirical protocol. It is assumed that this protocol can point out decision-making scenarios capable of conferring greater reliability to the design process and, consequently, to the paving design.

\section{MATERIALS AND METHODS}

\subsection{Materials}

The asphalt binder used in this investigation was modified with SBS copolymer (BETUFLEX 60/85-E), and it was supplied by Stratura Asfaltos S/A. The basic characteristics of this polymer-modified asphalt binder are shown in Table 1. The results of the aggregation characterization tests are shown in Table 2.

Table 1: Results of the basic tests conducted in the SBS-modified binder (BETUFLEX 60/85-E).

\begin{tabular}{|c|c|c|c|}
\hline CHARACTERISTIC & SPECIFICATION LIMITS (UNIT) & TEST METHOD & RESULT \\
\hline Penetration $25^{\circ} \mathrm{C}, 5 \mathrm{~s}, 100 \mathrm{~g}$ & $40-70(0.1 \mathrm{~mm})$ & DNIT ME 155/2010a [14] & $\begin{array}{l}57 \\
(0.1 \mathrm{~mm})\end{array}$ \\
\hline Softening Point (PA), min. & $60\left({ }^{\circ} \mathrm{C}\right)$ & DNIT ME 131/2010b [15] & $75\left({ }^{\circ} \mathrm{C}\right)$ \\
\hline Flash Point, min. & $235\left({ }^{\circ} \mathrm{C}\right)$ & $\begin{array}{l}\text { ABNT NBR 11341/2004a } \\
\text { [16] }\end{array}$ & $220\left({ }^{\circ} \mathrm{C}\right)$ \\
\hline $\begin{array}{l}\text { Brokfield viscosity at } 135^{\circ} \mathrm{C} \text {, } \\
\text { spindle } 21,20 \mathrm{rpm} \text {, max. }\end{array}$ & $3000(\mathrm{cP})$ & $\begin{array}{l}\text { ABNT NBR 15184/2004b } \\
\text { [17] }\end{array}$ & $1120(\mathrm{cP})$ \\
\hline $\begin{array}{l}\text { Brokfield viscosity at } 150^{\circ} \mathrm{C} \text {, } \\
\text { spindle } 21,50 \mathrm{rpm} \text {, max. }\end{array}$ & $2000(\mathrm{cP})$ & $\begin{array}{l}\text { ABNT NBR 15184/2004b } \\
{[17]}\end{array}$ & $620(\mathrm{cP})$ \\
\hline $\begin{array}{l}\text { Brokfield viscosity at } 177^{\circ} \mathrm{C}, \\
\text { spindle } 21,100 \mathrm{rpm}, \max .\end{array}$ & $1000(\mathrm{cP})$ & $\begin{array}{l}\text { ABNT NBR 15184/2004b } \\
\text { [17] }\end{array}$ & $235(\mathrm{cP})$ \\
\hline Phase Separation Test, max. & $5\left({ }^{\circ} \mathrm{C}\right)$ & $\begin{array}{l}\text { ABNT NBR 15166/2004c } \\
{[18]}\end{array}$ & $2.8\left({ }^{\circ} \mathrm{C}\right)$ \\
\hline $\begin{array}{l}\text { Elastic Recovery at } 25^{\circ} \mathrm{C}, 20 \mathrm{~cm} \text {, } \\
\text { min. }\end{array}$ & $85(\%)$ & - & $93(\%)$ \\
\hline \multicolumn{4}{|c|}{ Effect of heat and air - RTFOT, $163^{\circ} \mathrm{C}, 85$ minutes } \\
\hline Mass variation, max. & 1 (\% mass) & $\begin{array}{l}\text { ABNT NBR 15235/2006 } \\
{[19]}\end{array}$ & $\begin{array}{l}0.89(\% \\
\text { mass })\end{array}$ \\
\hline PA variation, max. & $(-5)$ to $7\left({ }^{\circ} \mathrm{C}\right)$ & DNIT ME $131 / 2010 b[15]$ & $0.5\left({ }^{\circ} \mathrm{C}\right)$ \\
\hline$\%$ Original Penetration, min. & $60(\%)$ & DNIT ME 155/2010a [14] & $73.5(\%)$ \\
\hline $\begin{array}{l}\% \text { Original Elastic Recovery at } \\
25^{\circ} \mathrm{C} \text {, min. }\end{array}$ & $80(\%)$ & DNIT ME 130/2010c [20] & $99.8(\%)$ \\
\hline
\end{tabular}


Table 2: Results of the characterization tests of the aggregates used in the study.

\begin{tabular}{l|l|l}
\hline CHARACTERIZATION TESTS ON AGGREGATES & STANDARD & RESULTS \\
\hline Determination of "Los Angeles" abrasion for coarse aggregate & DNER ME 035/1998a [21] & $44.92 \%$ \\
\hline Determination of adhesiveness to bituminous binders & DNER ME 078/1994a [22] & Unsatisfactory \\
\hline Determination of the Shape Index - Gravel 0 & DNER ME 086/1994b [23] & 0.59 \\
\hline Determination of the Shape Index - Gravel 1 & DNER ME 086/1994b [23] & 0.68 \\
\hline Determination of absorption - Gravel 0 & DNER ME 194/1998b [24] & $0.68 \%$ \\
\hline Determination of absorption - Gravel 1 & DNER ME 194/1998b [24] & $0.65 \%$ \\
\hline Determination of specific mass of fine aggregate & DNER ME 194/1998b [24] & $2.782 \mathrm{~g} / \mathrm{cm}^{3}$ \\
\hline Determination of real specific mass - Gravel 0 & DNER ME 081/1998c [25] & $2.791 \mathrm{~g} / \mathrm{cm}^{3}$ \\
\hline Determination of real specific mass - Gravel 1 & DNER ME 081/1998c [25] & $2.796 \mathrm{~g} / \mathrm{cm}^{3}$ \\
\hline
\end{tabular}

The results of the characterization of the asphalt binder and aggregates, except the adhesiveness of the binder to the aggregate, met technical specifications cited in Tables 1 and 2. The adhesiveness of the binder to the aggregate, which was measured according to the DNER ME 078/1994a method [22], was shown to be unsatisfactory. This limitation was addressed by means of the incorporation of $0.1 \%$ of additive by weight of the asphalt binder to improve adhesion. From the granulometric analysis carried out according to DNER ME 083/1998d [26], the compositions of the granulometric curves that fit the granulometric ranges $\mathrm{B}$ and $\mathrm{C}$ to dense-graded mixes of DNER ES 385/1999 [27] were determined, as illustrated in Figure 1. The design gradation curve for granulometric range B may be described as $32 \%$ stone powder, $41 \%$ crushed stone 0 and $27 \%$ crushed stone 1 , while the design gradation curve for granulometric range $\mathrm{C}$ is composed of $53 \%$ stone powder, $35 \%$ gravel 0 and $12 \%$ gravel 1 .

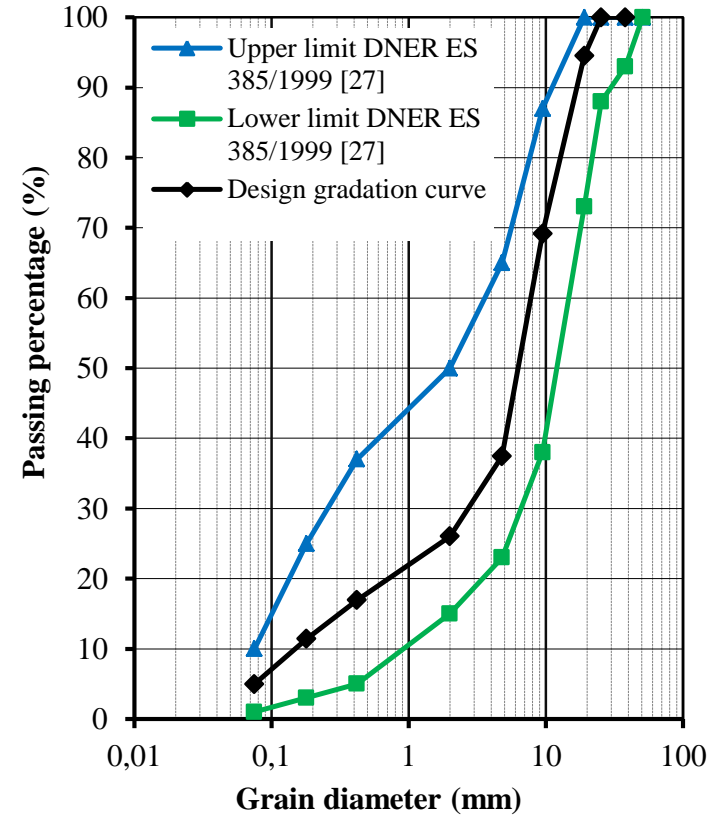

(a) Design gradation curve for granulometric range $\mathrm{B}$

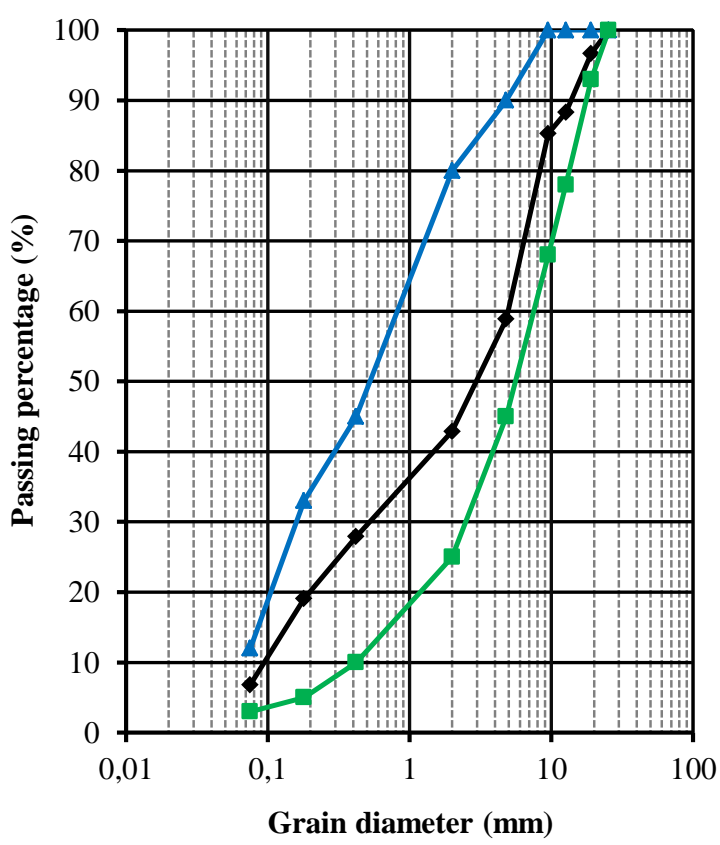

(b) Design gradation curve for granulometric range $\mathrm{C}$

Figure 1: Lower and upper limits of the DNER ES 385/1999 service specification [27] for the granulometric ranges B and $\mathrm{C}$ studied and their respective design gradation curves.

\subsection{Methods}

\subsubsection{Marshall mix design method}

In the design process of asphalt mixtures, the Marshall mix design method was used according to the DNER ME 043/1995 standard [28]. To determine the design content of the asphalt binder through the relationship 
between the voids content (VC) and voids filled with bitumen (VFB) parameters. Initially, asphalt mixtures were designed in five binder contents $(4.2 \%, 4.7 \%, 5.2 \%, 5.7 \%$ and $6.2 \%$ by weight). According to SENÇO [29], asphalt mixtures prepared with such binder contents tend to show higher stability and strength and lower air void percentages. The mixture of aggregates with the binder was defined as enough to obtain a specimen of approximately $6.3 \mathrm{~cm}$ in height, $10.0 \mathrm{~cm}$ in diameter and $1200 \mathrm{~g}$. The compaction energy corresponded to 75 strokes per face across the specimens.

From the graphical analysis of the VC and VFB values of the asphalt mixtures prepared with the above mentioned binder contents and by following the basic protocol contained in BERNUCCI et al. [30] and the limits established by DNER ES 385/1999 [27] for such parameters $(3 \% \leq \mathrm{VC} \leq 5 \% ; 75 \% \leq \mathrm{VFB} \leq$ $82 \%$ ), the specific binder design contents were determined for the asphalt mixtures corresponding to the granulometric range $\mathrm{B}$ and $\mathrm{C}$. For such binder contents, asphalt mixture samples were compacted and their volumetric parameters and basic mechanical properties were determined the volumetric parameters. Later, it was possible to verify their classification, within the limits established by DNER ES 385/1999 [27].

\subsubsection{Mechanical tests}

The Diametral Tensile Strength test according to the DNIT ME 136/2010d [31] standard and the Resilient Modulus test according to the procedures outlined by DNIT ME 135 / 2010e [32] were performed.

\subsubsection{Mechanistic-empirical methodology}

To analyze the sensitivity of the fatigue life of the surface course regarding the variation of its thickness, the soil resilience modules of the subgrade and asphalt mixture, the load applied by axis and the fatigue model adopted, a mechanistic-empirical protocol was used. Initially, different pre-design pavement structures were determined according to the empirical method presented in the DNIT Paving Manual [3], for a period of 10 years. In the mechanistic analysis, the Elsym 5 Program (KOPPERMAN et al. [33], FHWA [9]), aiming to obtain the structural responses necessary for the application of pavement fatigue life models was used. Figure 2 shows, in a simplified way, the methodological protocol applied in this study.

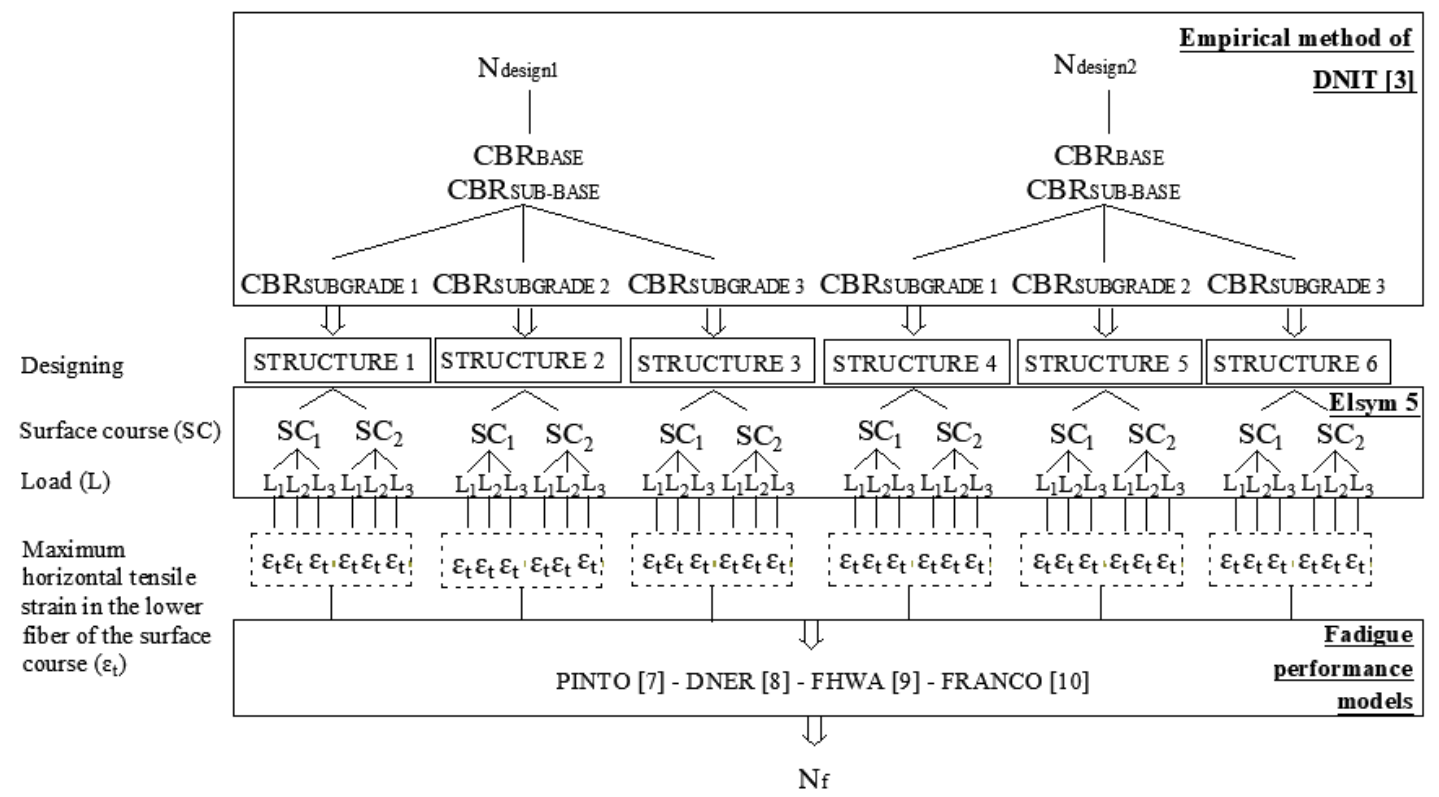

Figure 2: Methodological protocol used in the analysis of the mechanistic-empirical designing.

It should be noted that the design of the asphalt pavement structure according to the empirical method of DNIT [3] is performed according to the number of load repetitions of the standard axis of 8.2 tons (N) applied to the pavement, as well as the CBR (California Bearing Ratio) values of the materials that compose the respective layers, except for the surface course. The characteristics of the materials that compose the pavement structure in this study are shown in Table 3.

The determination of the thickness of the surface course was made according to the " $\mathrm{N}_{\text {design" }}$ [3]. For this purpose, two values of " $\mathrm{N}_{\text {design" }}$ " were chosen. In order to carry out simulations closer to real pavement structures, " $\mathrm{N}_{\text {design }}$ " values from real traffic situations were chosen. It was also decided to use materials in the 
base, sub-base and subgrade layers that would constitute typical road pavement structures, such as those in the state of Rio Grande do Sul, Brazil [34]. The fact that the Resilient Modulus of the sub-base is superior to the Resilient Modulus of the base finds support on common results obtained in retroanalysis of asphalt pavements in this state [3].

Table 3: Characteristics of the variables that dictate the pavement structure according to the DNIT method [3].

\begin{tabular}{|c|c|}
\hline VARIABLES & CHARACTERISTICS \\
\hline $\begin{array}{l}\text { Number of load repetitions for the } \\
\text { standard axis of } 8.2 \text { tons }\end{array}$ & $\begin{array}{l}-\mathrm{N}_{\text {design1 }}=1.56 \times 10^{7}: \text { number of load repetitions for the standard axis of } 8.2 \text { tons } \\
\text { in } 2013 \text { at } \mathrm{km} 541 \text { of BR } 116 \text {, in the municipality of Pavão, state of Rio Grande } \\
\text { do Sul [34]; } \\
\text { - } \mathrm{N}_{\text {design2 }}=10.4 \times 10^{7}: \text { number of load repetitions for the standard axis of } 8.2 \text { tons } \\
\text { in } 2013 \text { at km } 816 \text { of BR } 040 \text {, in the municipality of Simão Pereira, state of Rio } \\
\text { Grande do Sul [34]. }\end{array}$ \\
\hline Asphalt mix & $\begin{array}{l}\text { - Bituminous concrete with asphalt binder modified by polymer type SBS } \\
\text { (BETUFLEX 60/85-E). }\end{array}$ \\
\hline Base & $\begin{array}{l}\text { - } \mathrm{RM}=250 \mathrm{MPa} \\
\text { - Poisson's ratio equal to } 0.35 \text {. }\end{array}$ \\
\hline Sub-base with dry macadam & $\begin{array}{l}\text { - } \mathrm{RM}=300 \mathrm{MPa} \\
\text { - Poisson's ratio equal to } 0.35 \text {. }\end{array}$ \\
\hline Subgrade soil & $\begin{array}{l}-\mathrm{CBR}_{\text {SUBGRADE } 1}=4 \% \text { and } \mathrm{RM}=40 \mathrm{MPa} \\
-\mathrm{CBR}_{\text {SUBGRADE } 2}=10 \% \text { and } \mathrm{RM}=100 \mathrm{MPa} \\
-\mathrm{CBR}_{\text {SUBGRADE } 3}=16 \% \text { and } \mathrm{RM}=160 \mathrm{MPa} . \\
- \text { Poisson's ratio equal to } 0.35 .\end{array}$ \\
\hline
\end{tabular}

The mechanistic analysis consisted of verifying the performance of the pavement structure based on failure of the surface course by fatigue cracking. This was made by determining the " $\mathrm{N}_{\mathrm{f}}$ " number in the fatigue performance models of the surface course, see equations in Table 4. If this number is equal or exceeds the number " $\mathrm{N}_{\text {design }}$ ", the designing was considered appropriate for paving applications.

Table 4: Fatigue performance models of the surface course applied in the mechanistic-empirical method adopted in the research.

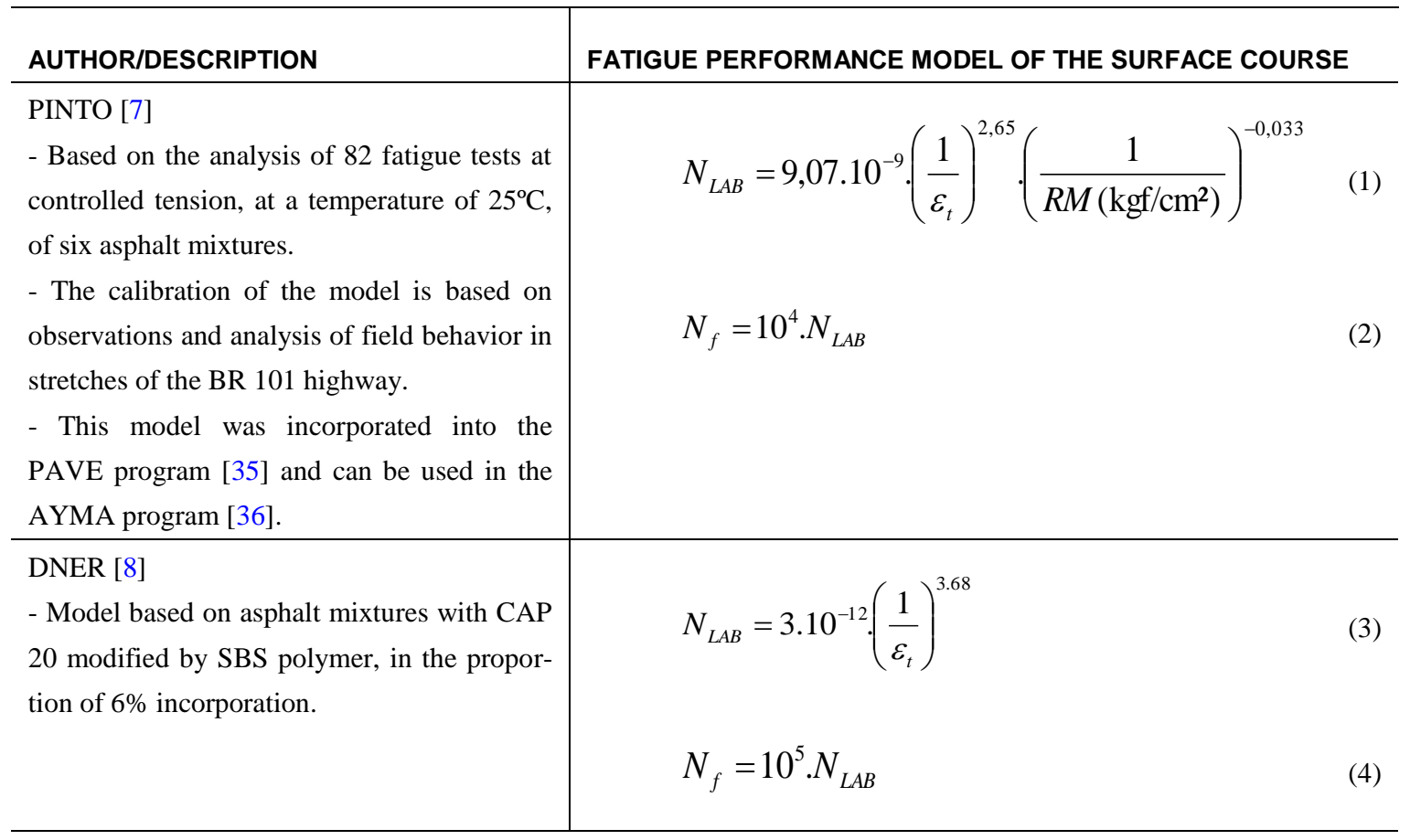




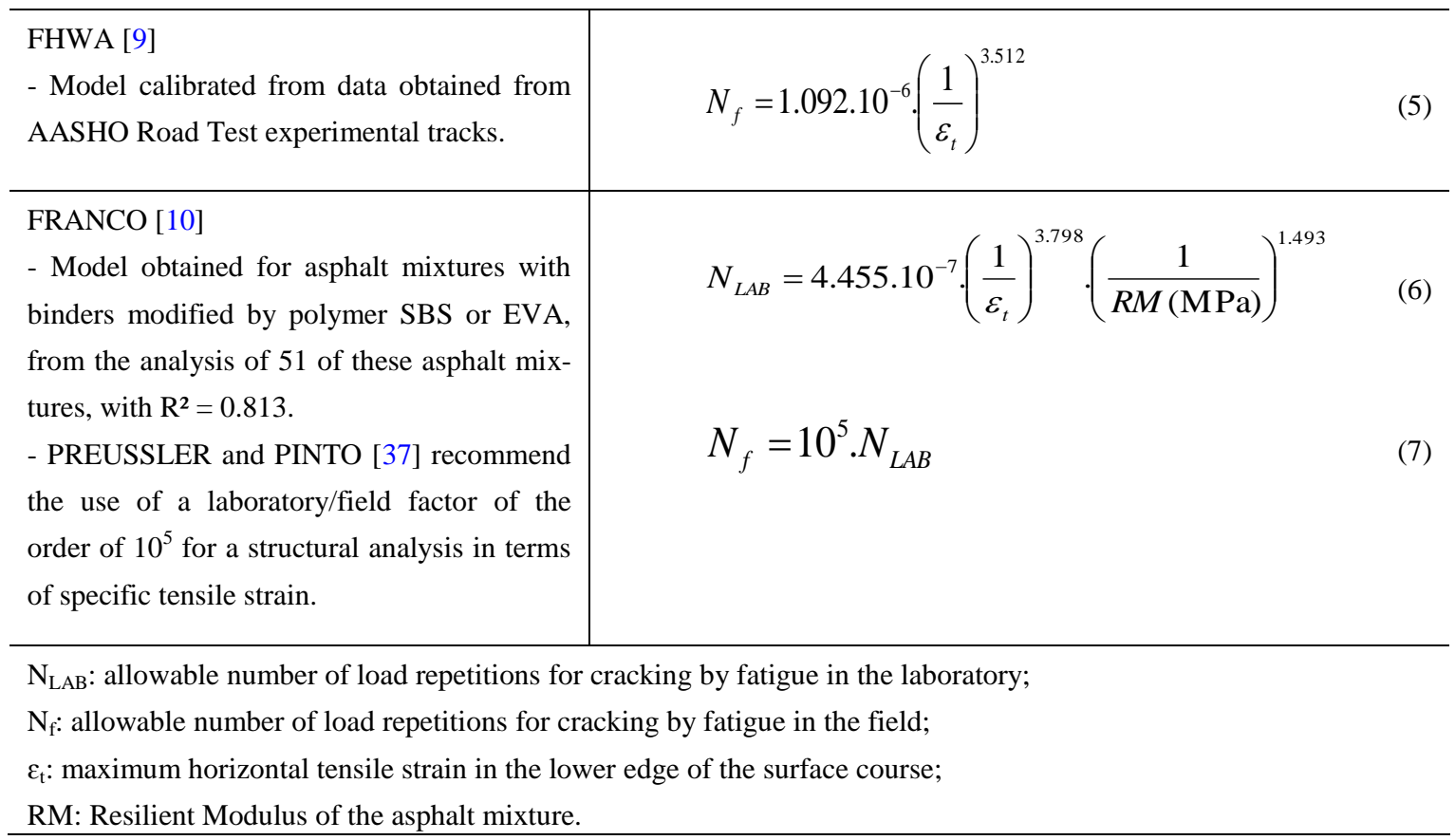

To determine the maximum horizontal tensile strain in the lower edge of the surface course $\left(\varepsilon_{t}\right)$, the Elsym 5 program was used. The input data were related to the number of layers and their corresponding thicknesses, as well as the Resilient Moduli and the Poisson's ratios of the structural layers of the pavement and the subgrade. The Resilient Modulus of the surface course, which may be designated as surface course 1 $\left(\mathrm{SC}_{1}\right)$ or surface course $2\left(\mathrm{SC}_{2}\right)$ depending on the gradation curve (B and $\mathrm{C}$, respectively), was determined through mechanical testing as shown above.

Then, the following loading data were considered in the analysis: the load value per tire (L/4), the pressure of each tire ( $80 \mathrm{psi}$ or $\left.5.63 \mathrm{kgf} / \mathrm{cm}^{2}\right)$ and the load positioning along the $\mathrm{X}$ axis. As the single axle with double wheels is symmetric in relation to the $\mathrm{X}$ axis, only the loads on the left side of the axis were reported, in positions $X=0 \mathrm{~cm}$ and $X=34 \mathrm{~cm}$. This study took into account the following load levels per axle:

- $\mathrm{L}_{1}=80 \mathrm{kN}$ ( $\left.8.2 \mathrm{tf}\right)$ : load corresponding to the standard axis of 18,000lb;

- $\mathrm{L}_{2}=98 \mathrm{kN}(10.0 \mathrm{tf})$ : maximum load allowed by Brazilian legislation for single axle with double wheels;

- $\mathrm{L}_{3}=118 \mathrm{kN}(12.0 \mathrm{tf})$ : load $20 \%$ above the maximum allowed value and with the percentage of $5 \%$ as the maximum tolerance. The objective of adopting a load $20 \%$ above the one allowed was to expose the consequences caused to asphalt pavement structures researched when there is excess load on the axles of commercial vehicles [38].

Finally, the reference points in the Cartesian axes $(\mathrm{X}, \mathrm{Y}, \mathrm{Z})$ were determined for conducting the structural analyses. In this case, the most critical points were defined as the places where the load is applied, in centimeters, either in " $\mathrm{X}$ " equal to $0 \mathrm{~cm}$ or equal to $34 \mathrm{~cm}$. The point positioned on the " $\mathrm{Z}$ " axis corresponds to the location of the lower edge of the surface course, that is, the interface between the surface course and the base layer. Its value was dependent on the thickness of the surface course according to the DNIT design method [3].

From the maximum horizontal tensile strain values in the lower edge of the surface course the number of load repetitions to fatigue failure $\left(\mathrm{N}_{\mathrm{f}}\right)$ and for each scenario were determined. The models reported in Table 4 were compared with the number of load repetitions defined in the design (" $\mathrm{N}_{\text {design1 }}$ " or " $\mathrm{N}_{\text {designz }}$ "). When the " $\mathrm{N}_{\mathrm{f}}$ " value is lower than the value of " $\mathrm{N}_{\text {design" }}$ ", the pavement structure needs to be redesigned because of the hypothesis of premature failure by fatigue cracking.

\section{RESULTS AND DISCUSSION}

\subsection{Marshall mix design}

From the application of the protocol contained in BERNUCCI et al. [30] and using the results of the volumetric parameters "VC" and "VFB" of the asphalt mixtures of granulometric ranges B and $\mathrm{C}$, the values 
of $4.80 \%$ and $5.20 \%$ were defined for the contents of asphalt binder in the design asphalt mixtures of these respective granulometric range.

For the specimens molded with the asphalt mixtures designed for the granulometric ranges $\mathrm{B}\left(\mathrm{AMD}_{\mathrm{B}}\right)$ and $\mathrm{C}\left(\mathrm{AMD}_{\mathrm{C}}\right)$, the average values of the volumetric parameters VC and VFB and the mechanical parameters Marshall Stability, Marshall Flow, Diametral Tensile Strength (TS) and Resilient Modulus (RM) were determined. These values were compared with the limiting values established by DNER ES 385/1999 [27] for such parameters (except for RM), as shown in Figure 3.
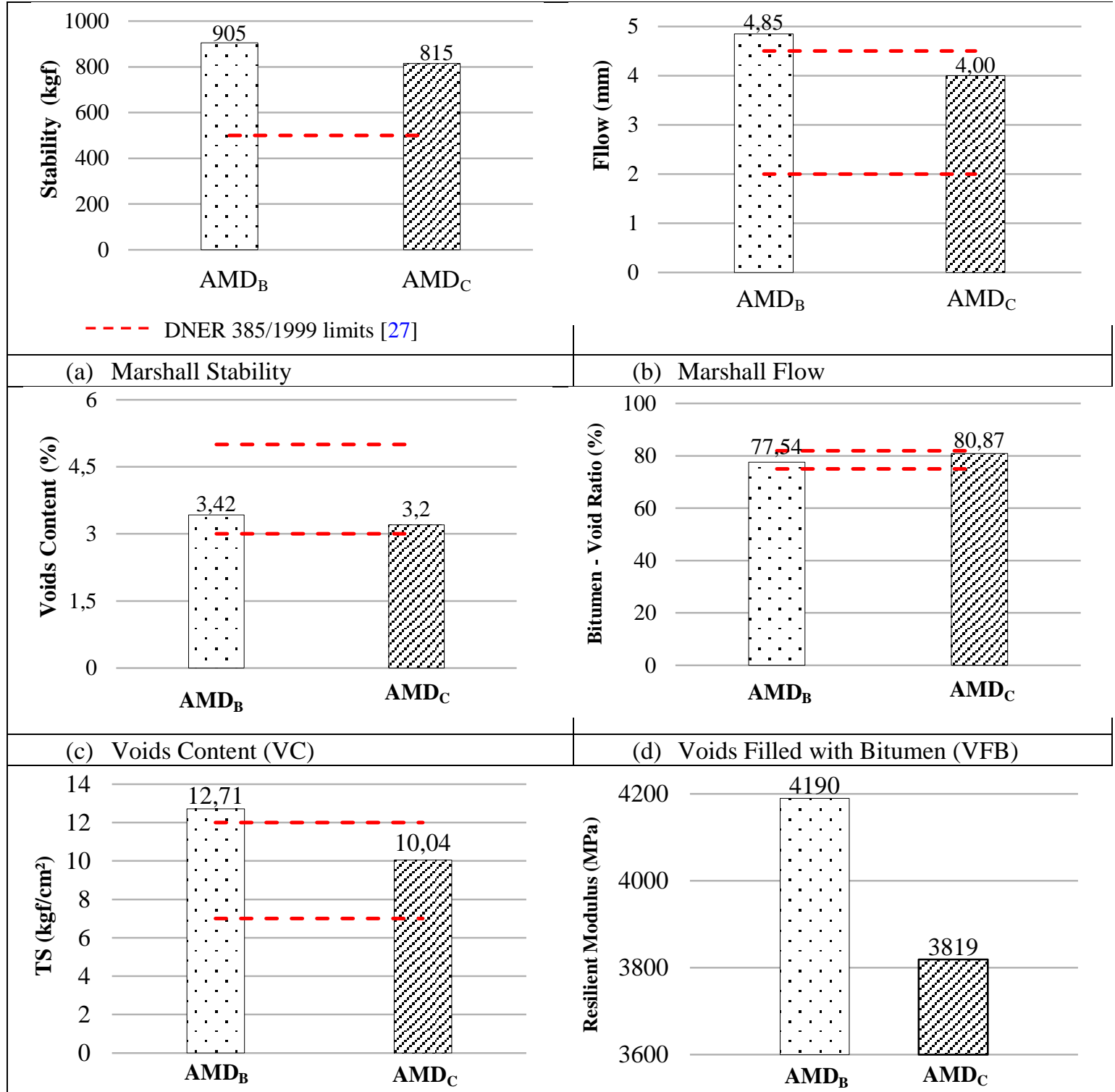

(d) Voids Filled with Bitumen (VFB)

(e) Diametral Tensile Strength (TS)

(f) Resilient Modulus (RM)

Figure 3: Volumetric parameters (VC, VFB), Marshall parameters (Stability, Flow), TS and RM for the asphalt mixtures designed for each of the granulometric ranges $\mathrm{B}\left(\mathrm{AMD}_{\mathrm{B}}\right)$ and $\mathrm{C}\left(\mathrm{AMD}_{\mathrm{C}}\right)$.

The values of the volumetric parameters (VC and VFB) of the asphalt mixtures met the requirements of the DNER ES 385/1999 specification [27]. However, it should be noted that $\mathrm{AMD}_{\mathrm{B}}$ presented the Marshall Flow value $0.35 \mathrm{~mm}$ higher than the maximum limit established in this same specification. Yet, it is worth mentioning that this parameter is no longer used [39] and the DNIT ES 031/2006 specification [40] is applied only to asphalt concrete mixtures without the addition of polymers. This new specification does not even make reference to the Marshall Flow parameter.

From the analysis of the results of TS, it is noted that the values obtained for the $\mathrm{AMD}_{\mathrm{C}}$ asphalt mixtures are in the range of $7 \mathrm{kgf} / \mathrm{cm}^{2}$ to $12 \mathrm{kgf} / \mathrm{cm}^{2}$, in accordance with the DNER ES $385 / 1999$ 
specification [27]. In turn, the $\mathrm{AMD}_{\mathrm{B}}$ mixture specimens exceeded the upper limit foreseen by them, but their results were close to the maximum allowed limit.

It is known that the asphalt binder provides flexibility and elasticity to bituminous mixtures, while the coarse aggregate provides greater stiffness to them. Based on this, the $\mathrm{AMD}_{\mathrm{B}}$ mixtures were, the ones with the highest percentage of coarse aggregate and also presented values of Marshall Stability, TS and RM superior to those of the $\mathrm{AMD}_{\mathrm{C}}$ mixtures.

The values of the volumetric (VC and VFB) and mechanical (Marshall Stability and TS) parameters of the $\mathrm{AMD}_{\mathrm{B}}$ and $\mathrm{AMD}_{\mathrm{C}}$ mixtures meet the limits established by DNER ES 385/1999 [27]. Thus, such asphalt mixtures can be used as an surface course in pavement structures.

\subsection{Mechanistic-empirical analysis}

Figure 4 reports the six asphalt pavement structures designed in accordance with the empirical method of DNIT [3] and by considering the different values of " $\mathrm{N}_{\text {design" }}$ " and the three subgrade soils, as shown in Table

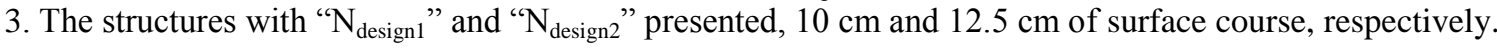

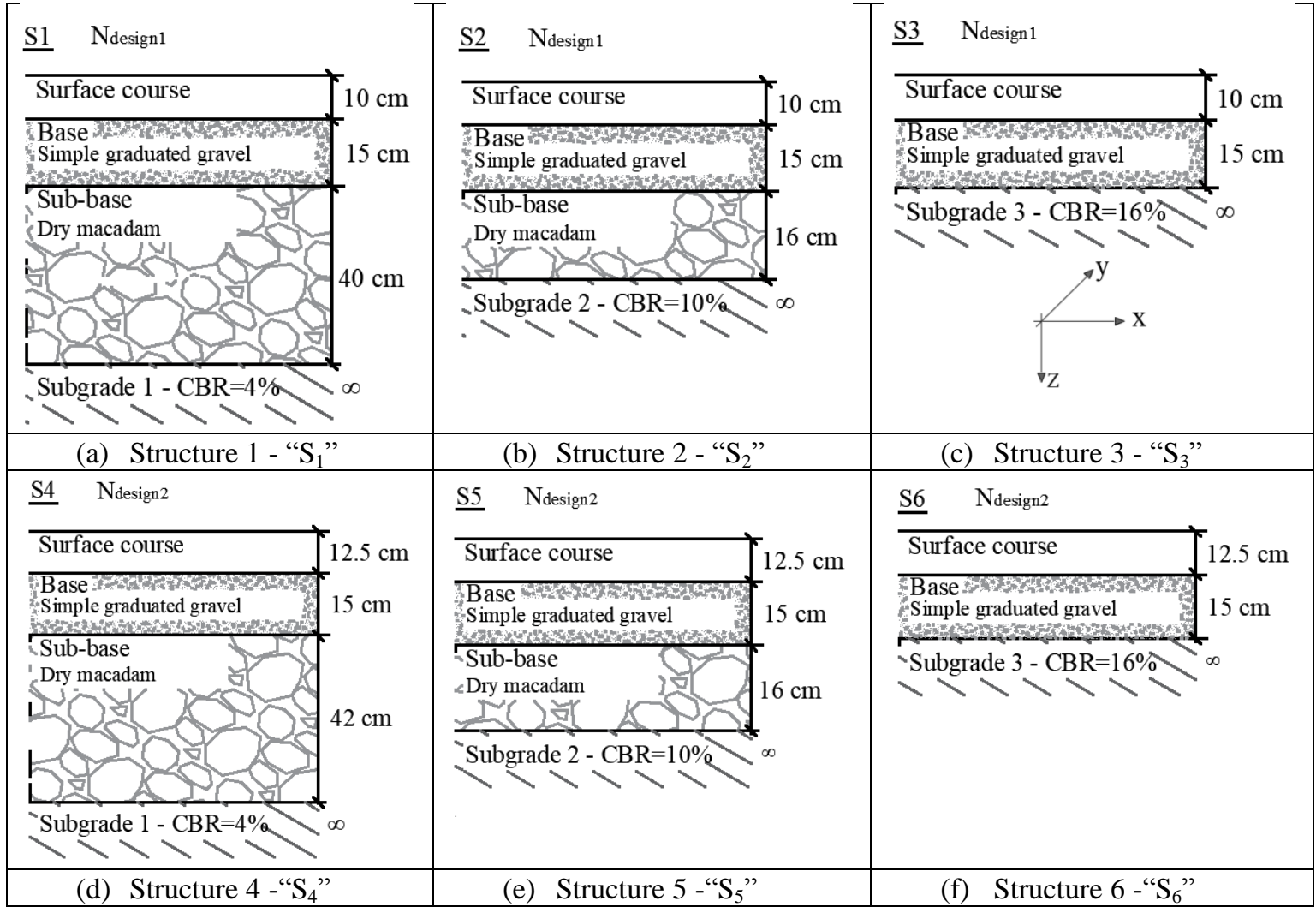

Figure 4: Asphalt pavement structures designed according to the DNIT method [3].

From the simulation of these structures in the Elsym 5 software and with the application of the axle loads " $\mathrm{L}_{1}$ ", " $\mathrm{L}_{2}$ " and " $\mathrm{L}_{3}$ ", the maximum horizontalspecific strain of traction $\left(\varepsilon_{\text {tmax }}\right)$ were determined in the lower edge of the surface course. In structures in which asphalt layer thickness is $10 \mathrm{~cm}$ (" $\mathrm{S}_{1}$ ", " $\mathrm{S}_{2}$ " and " $\mathrm{S}_{3}$ "), the values etmax were determined at point $\mathrm{A}(0 ; 0 ; 9.99)$, and in structures whose asphalt layer thickness is $12.5 \mathrm{~cm}$ (" $\mathrm{S}_{4}$ ", " $\mathrm{S}_{5}$ " and " $\mathrm{S}_{6}$ "), the values $\varepsilon$ tmax were determined at point $\mathrm{B}(0 ; 0 ; 12.49)$

Figures 5 and 6 represent the results of etmax corresponding to $\mathrm{AMD}_{\mathrm{B}}\left(\mathrm{SC}_{1}\right)$ and $\mathrm{AMD}_{\mathrm{C}}\left(\mathrm{SC}_{2}\right)$ asphalt mixtures, respectively. 


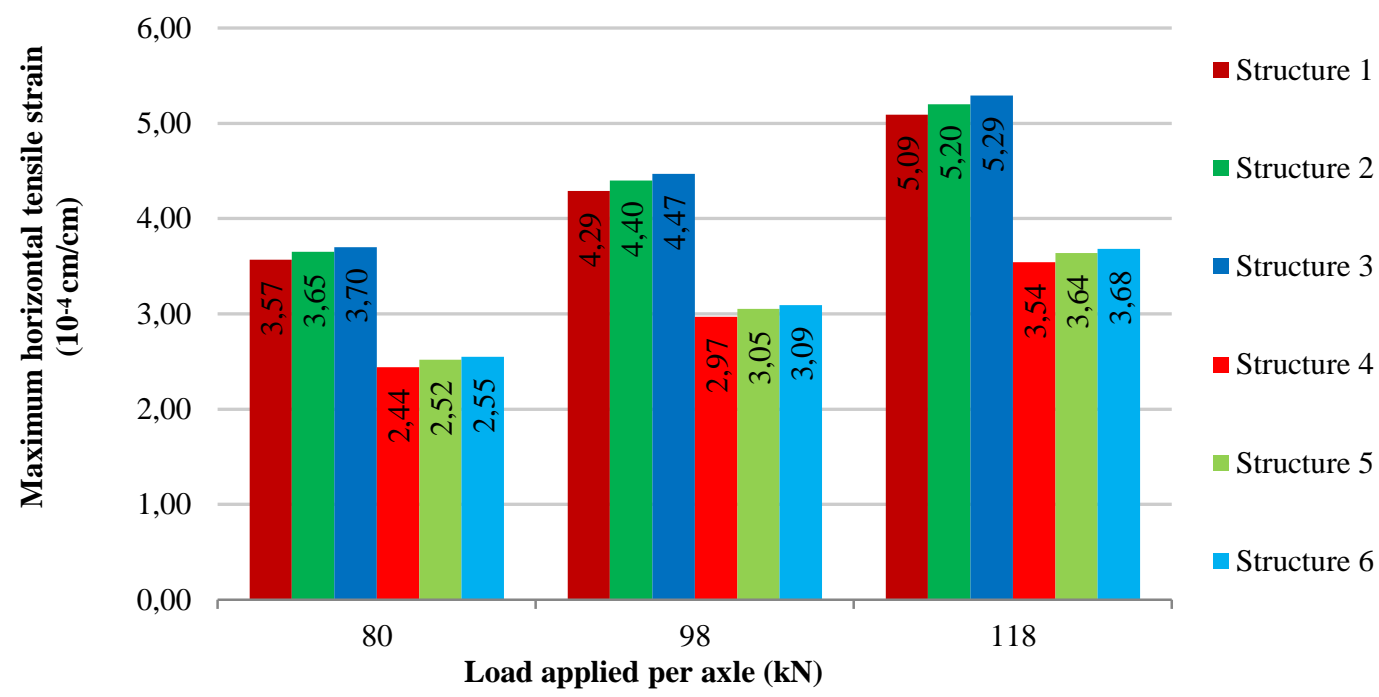

Figure 5: Results of the maximum horizontal tensile strain in the lower edge of the surface course corresponding to $\operatorname{AMD}_{\mathrm{B}}\left(\mathrm{SC}_{1}\right)$.

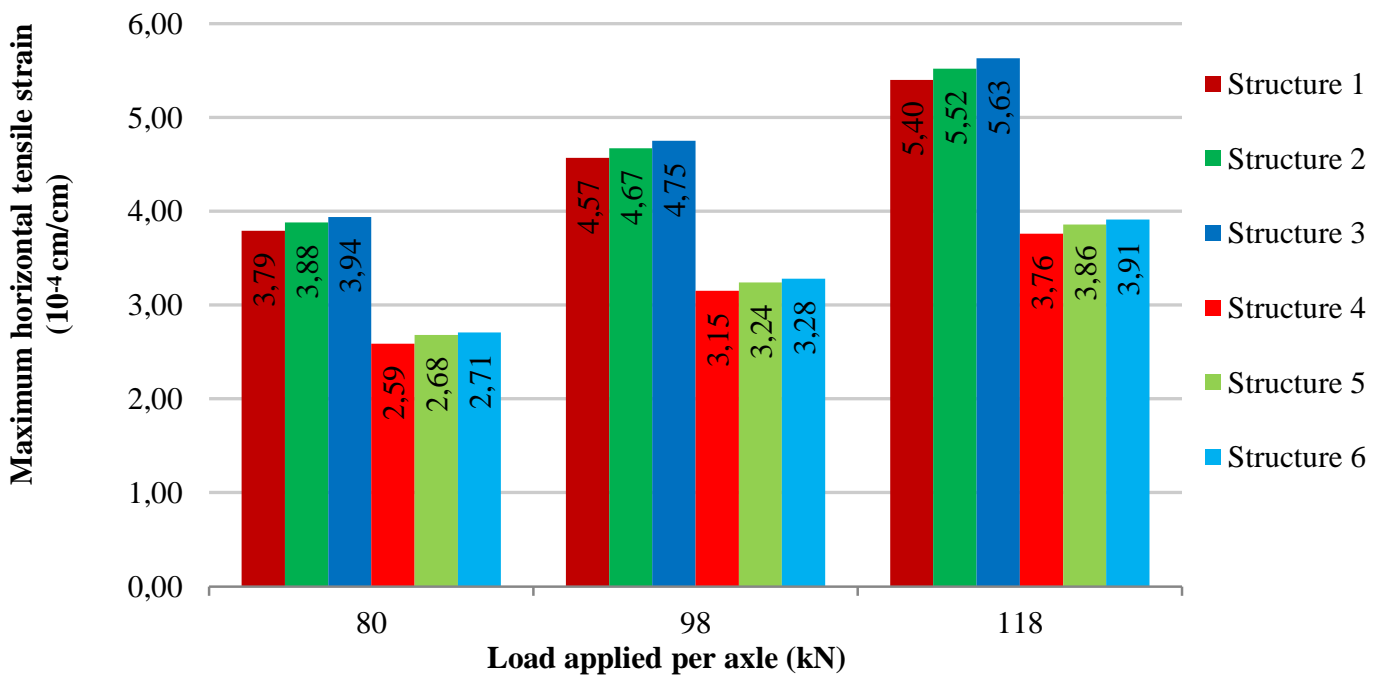

Figure 6: Results of the maximum horizontal tensile strain in the lower edge of the surface course corresponding to $\mathrm{AMD}_{\mathrm{C}}\left(\mathrm{SC}_{2}\right)$.

It should be noted that the $\varepsilon$ t values for the " $\mathrm{S}_{1}$ ", " $\mathrm{S}_{2}$ " and " $\mathrm{S}_{3}$ " structures are, on average, approximately $19.80 \%$ higher than those presented by the " $\mathrm{S}_{4}$ ", " $\mathrm{S}_{5}$ " and "S " structures, respectively. Such behavior is explained by the difference of $2.50 \mathrm{~cm}$ between the thicknesses of the surface course of each structure, since those with greater thickness presented lower strain values.

Regardless of the applied load, the "S3" and "S6" structures presented the worst performance in relation to the $\varepsilon$ t value. In both cases, the absence of the sub-base layer caused an increase in stresses in the top of the subgrade, which explains the increase in tensile strains in the lower edge of the surface course. The et value at the bottom of the asphalt layer was higher in structures with a higher applied load per axle. The $20 \%$ increase in load $(118 \mathrm{kN})$ in relation to the maximum allowed value provided increases of about $18.80 \%$ in the strains of the surface course, which corresponds to both asphalt mixtures of the design under study. This is an evidence of the prejuducial structural implications that increased load on the pavement design process can cause.

It was observed that the values of etmáx of the structures whose surface course corresponds to $\mathrm{AMD}_{\mathrm{C}}$ $(\mathrm{RM}=3819 \mathrm{MPa})$ (Figure 6) were on average 6.20\% higher than the values presented by the structures whose surface course corresponds to $\mathrm{AMD}_{\mathrm{B}}(\mathrm{RM}=4190 \mathrm{MPa}$ ) (Figure 5). A possible explanation for this fact is the greater resilient stiffness of $\mathrm{AMD}_{\mathrm{B}}$, considering that the $\mathrm{RM}$ and the said strain present an inverse proportionality. 
The values of "Nf" according to the application of the fatigue performance models proposed by PINTO [7], DNER [8], FHWA [9] and FRANCO [10] to each of the possible scenarios, are presented in Figures 7 and 8 for the parameters " $\mathrm{N}_{\text {design1" }}$ " and " $\mathrm{N}_{\text {design2 }}$ ", respectively. Due to the great amplitude between the values of " $\mathrm{N}_{\mathrm{f}}$ " and " $\mathrm{N}_{\text {design }}$ ", the graphs were plotted on a logarithmic scale for better representation.

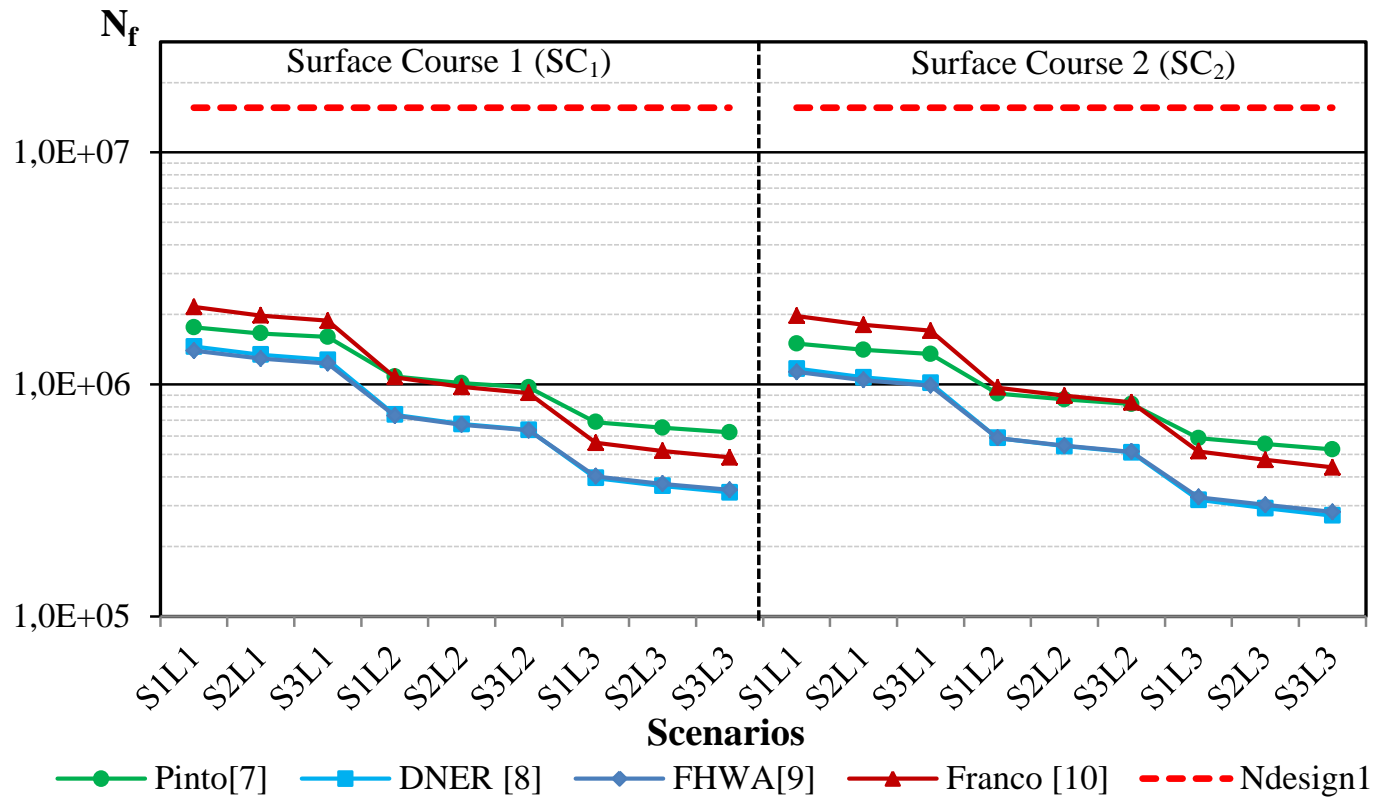

Figure 7: " $\mathrm{N}_{\mathrm{f}}$ " values obtained by the different fatigue models for the " $\mathrm{S}_{1}$ ", " $\mathrm{S}_{2}$ " and " $\mathrm{S}_{3}$ " structures.

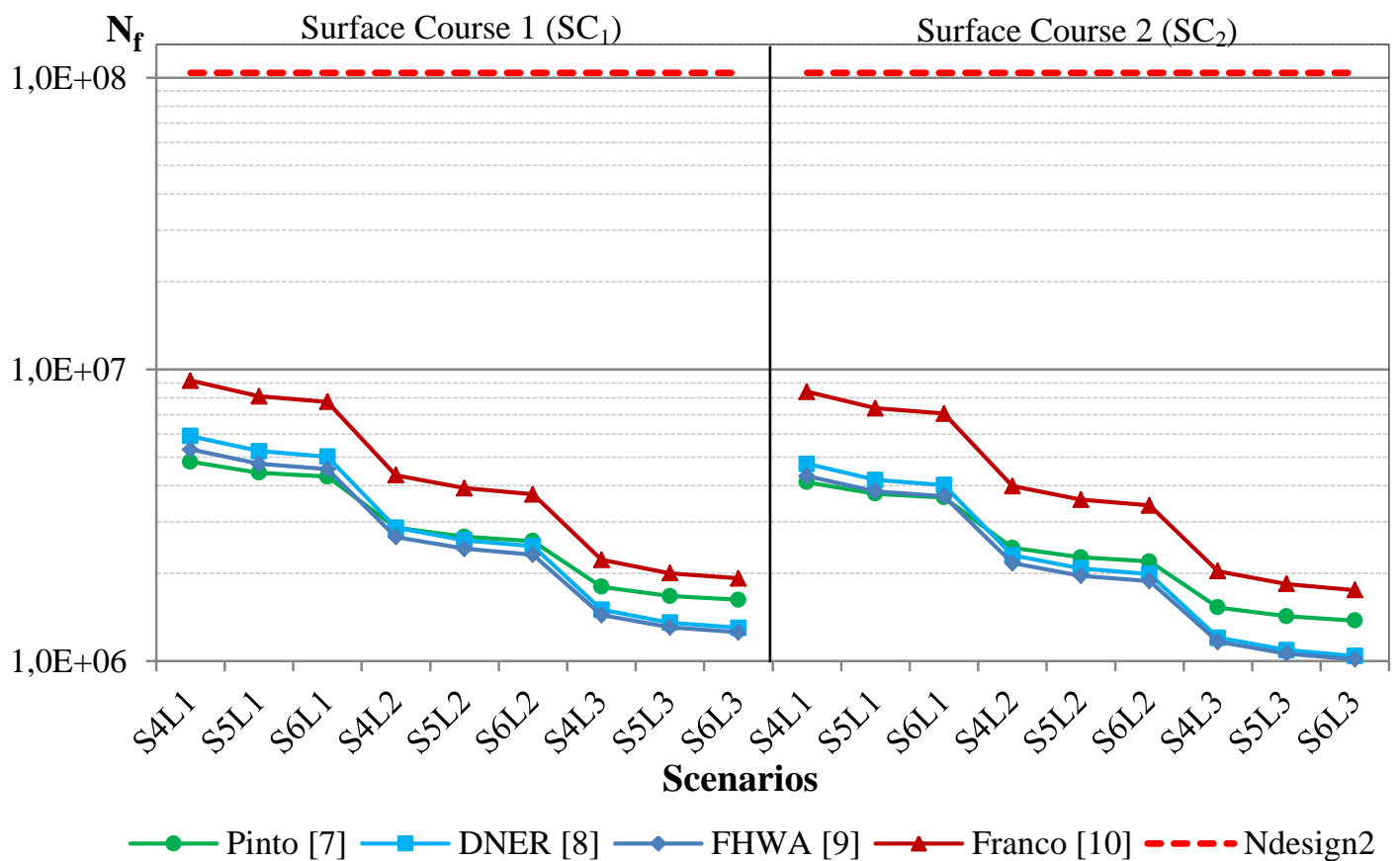

Figure 8: "N $\mathrm{N}_{\mathrm{f}}$ " values obtained by the different fatigue models for the " $\mathrm{S}_{4}$ ", " $\mathrm{S}_{5}$ " and " $\mathrm{S}_{6}$ " structures.

According to the results presented in Figures 7 and 8, it is noted that, regardless of the value " $\mathrm{N}_{\text {design" }}$ " and the applied fatigue model, the number of load repetitions for the standard axis of 8.2 tons is lower than the number of load repetitions for the standard axis of 8.2 tons considered in the designing of the pavement

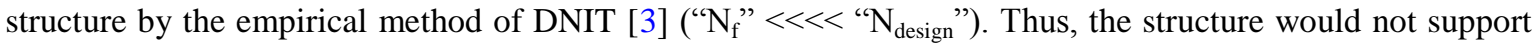
the expected loads and fatigue cracking would occur in the surface course before completing the 10-year design life.

The proximity of the " $\mathrm{N}_{\mathrm{f}}$ " values determined by the application of the fatigue performance models proposed by DNER [8] and FHWA [9] is verified for both "Ndesign" bands and in all scenarios. In this 
regard, it is worth noting that the models proposed by DNER [8] and FHWA [9] are the only ones that relate the " $\mathrm{N}_{\mathrm{f}}$ " value to the of the maximum horizontal tensile strain value in the lower edge of the surface course, as shown in Table 4.

The values of " $\mathrm{N}_{\mathrm{f}}$ " established by the application of the model proposed by FRANCO [10] are higher and are different in relation to most of the values established by the other models under study. This fact occurs mainly in scenarios with the application of the lowest load values that, as observed in Figures 5 and 6 , cause lower strains in the surface course and consequently higher values of " $\mathrm{N}$ ", due to the ratio of inverse proportionality between the value of " $\mathrm{N}$ " and the " $\varepsilon_{\mathrm{t}}$ ". It is noteworthy that, in the determination of the values of "N", the model proposed by FRANCO [10], different from the other ones, considers the inverse of the $\mathrm{RM}$ of the susface course and raises the term referring to "$\varepsilon t$ " to a higher power than those presented by the other fatigue models

It is noted that, regardless of the applied model, when comparing the values of " $\mathrm{Nf}$ " of the structures constituted by "SC " $(\mathrm{RM}=4190 \mathrm{MPa})$ and " $\mathrm{SC}_{2}$ " $(\mathrm{RM}=3819 \mathrm{MPa})$, the $\mathrm{SC} 1$ structures (with a greater Resilience Modulus) have higher "Nf" values than those of " $\mathrm{SC}_{2}$ " structures and it is possible to infer that the highest values of surface course Resilience Module provide higher "N" values.

It is observed that the values of the " $\mathrm{N}_{\mathrm{f}}$ " defined by the application of the model proposed by PINTO [7], compared with those defined by the application of the other fatigue performance models, undergo less change with the variation of the load applied in the pavement structure and with the thickness of the surface course. This demonstrates that the " $\varepsilon_{\mathrm{t}}$ " influence less on the value of the " $\mathrm{N}_{\mathrm{f}}$ " defined by the application of the model proposed by PINTO [7] when compared to the other models studied.

Thus, in light of the previous observations, it appears that the fatigue performance models proposed by DNER [8] and FHWA [9] are the most recommended for the mechanistic analysis of the designing of the investigated asphalt pavement structures.

In order to determine the " $\mathrm{N}_{\mathrm{f}}$ " value that is at least equal to "Ndesign" for all the selected pavement

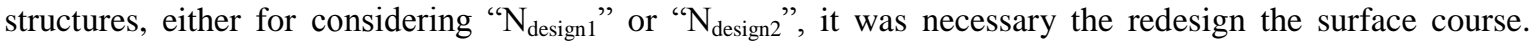
Since the objective was to verify the thickness of the surface course determined by the fatigue performance forecasting models between the scenarios, the redesign process was performed only for the scenarios of the structures with " $\mathrm{SC}_{1}$ " surface course, with a greater Resilient Modulus, as shown in Figure 9 for " $\mathrm{N}_{\text {design1 }}$ " and " $\mathrm{N}_{\text {design2". }}$

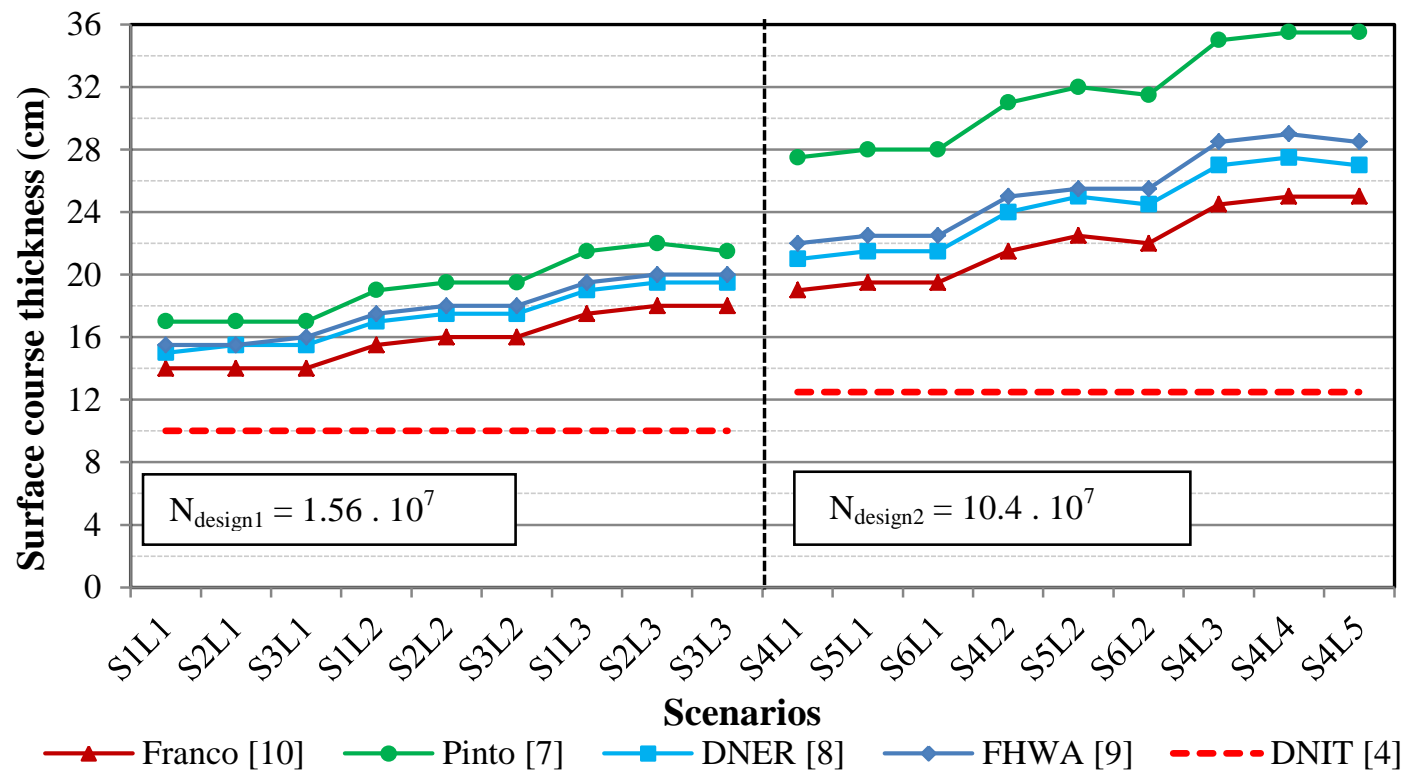

Figure 9: Redesigning the thickness of the surface course for structures made up of " $\mathrm{SC}_{1}$ ".

In view of the results presented in Figure 9, it is noted that the difference between the thickness of the asphalt layer defined by the DNIT method [6] and those defined by the fatigue performance prediction

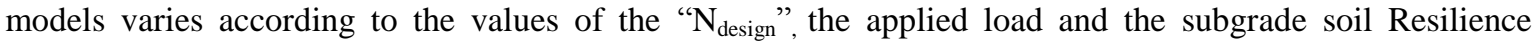
Modulus. Thus, it was possible to infer that the factors that most influenced the redesign of the thickness of

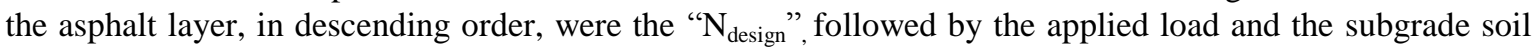
Resilience Modulus. 
It is observed, from the application of the models for predicting the number of allowable requests for fatigue cracking proposed by DNER [8] and FHWA [9], that the values of the thicknesses of the surface course for both models are approximately equal.

From the results, it is observed that the model proposed by FRANCO [10] is the less conservative one, especially when compared to the model from PINTO [7]. The thicknes variations in the thickness of the surface course according to these models were about $3.0 \mathrm{~cm}$. However, when comparing the thicknesses of the surface course of the models between the structures with different " $\mathrm{N}_{\text {design }}$ " values, it is noted that the thicknesses determined by the model from PINTO [7] do not differ from those obtained by applying the models proposed by DNER [8] and FHWA [9], as occurs for " $\mathrm{N}_{\text {design2". }}$

There is also a variation in determining the thickness of the surface course as to the application of different fatigue models, especially in scenarios where the applied load values are higher. In these cases, the trends in the results obtained by the model proposed by PINTO [7] is significantly different from those according to the models proposed by FHWA [9], DNER [8] and FRANCO [10].

\section{CONCLUSIONS}

Based on the results presented in this study, it can be concluded that fatigue performance and asphalt layer design varied according to fatigue models applied in different scenarios. However, the sensitivity of performance to surface course fatigue determined by these models, given the variations of the factors studied, was approximately the same. Thus, it is concluded that the fatigue of asphalt layer is more sensitive to the variation of the thickness of the asphalt layer than to the variation of the applied load value, followed by the subgrade soil Resilience Modulus.

Among the fatigue performance models applied in this study, it is concluded that those proposed by DNER [8] and FHWA [9] are the most recommended for mechanistic-empirical analysis of asphalt pavement structure design, since they resulted in " $\mathrm{N}_{\mathrm{f}}$ " and surface course thickness values approximately equal.

It is observed the limitation of the empirical method of design the DNIT [4], evidencing the importance of the adoption of mechanistic-empirical methods, in which the Resilience Modulus and the Poisson coefficient of the materials of the structural layers of the pavement are considered. It is also emphasized the need to carry out, through weighing stations installed in stretches of the Brazilian paved road network, more rigorous and efficient inspections regarding the maximum load applied on the pavements.

\section{ACKNOWLEDGMENT}

The authors would like to thank the Capes Foundation, for funding the master's scholarship, and the Laboratório de Pavimentação da Universidade Federal de Juiz de Fora, for carrying out the Resilient Modulus tests.

\section{BIBLIOGRAPHY}

[1] CANESTRARI, F., INGRASSIA, L.P., "A review of top-down craking in asphalt pavements: Causes, models, experimental tools and future challenges", Journal of Transportation Engineering, v. 7, n. 5, pp. 541 572, October 2020.

[2] SANTOS, T.A., SILVA JÚNIOR, C.A.P.DA, FONTENELE, H.B. "The effect of axle load spctra from AASHTO method on flexible pavement performance", Acta Scientiarum. Technology, v. 41, n. 1, p. e35117, May 2019.

[3] DEPARTAMENTO NACIONAL DE INFRAESTRUTURA DE TRANSPORTES - DNIT, Manual de pavimentação, 3 ed., Diretoria de Planejamento e Pesquisa Coordenação Geral de Estudos e Pesquisa. Instituto de Pesquisas Rodoviárias, Rio de Janeiro, 2006.

[4] MEDINA, J., MOTTA, L.M.G., Mecânica dos pavimentos, 3 ed., Rio de Janeiro, Interciência, 2015.

[5] DIAZ MARTINEZ, M., PEREZ, I., "Mechanistic-empirical pavement design guide: features and distinctive elements", Revista la construcción, v. 14, n. 1, pp.32-40, April 2015.

[6] SANTIAGO, L.S., SILVA, S.A.T., SOARES, J.B. "Determinação do dano em pavimentos asfálticos por meio da combinação do modelo S-VECD com análises elásticas". Transportes, v. 26, n. 2, pp. 31-43, August 2018.

[7] PINTO S., "Estudo do comportamento à fadiga de misturas betuminosas e aplicação na avaliação estrutural de pavimentos”, Thesis D.Sc., COPPE/UFRJ, Rio de Janeiro, RJ, 1991.

[8] DEPARTAMENTO NACIONAL DE ESTRADAS DE RODAGEM - DNER, Pesquisas de asfaltos modificados por polímeros - Relatório Final Tomo I e II, Rio de Janeiro, 1998. 
[9] FHWA - FEDERAL HIGHWAY ADMINISTRATION. Pavement Management Systems, https://www.fhwa.dot.gov/publications/lists/advancedresearch/pubs.cfm. Accessed May 2019.

[10] FRANCO, F.A.C.D.P., "Método de dimensionamento mecanístico-empírico de pavimentos asfálticos", Thesis D.Sc., Universidade Federal do Rio de Janeiro, Rio de Janeiro, RJ, Brasil, 2007.

[11] SCHWARTZ, C.W., LI, R., CEYLAN, H., et al., "Global sensitivity analysis of mechanistic-empirical performance predictions for flexible pavements", Journal of the Transportation Research Board, v. 2368, n. 1, pp. 12-23, January 2013.

[12] PELISSON, N.D., FERNANDES JUNIOR, J.L., SILVA JUNIOR, C.A.P., et al., "Avaliação de desempenho pelo MEPDG: o efeito da variação de espessuras de pavimentos flexíveis", Journal of Transport Literature, v. 9, n. 1, pp. 20-24, January 2015.

[13] ALBUQUERQUE, F.S., MENDONÇA, A.T., "Análise crítica e ajuste de modelos de previsão de fadiga com análise incremental de danos para BGTC executada em pavimento asfáltico semirrígido", Transportes, v. 25, n. 2, pp. 107-123, August 2017.

[14] DEPARTAMENTO NACIONAL DE INFRAESTRUTURA DE TRANSPORTES - DNIT, DNIT 155/2010 ME: Material asfáltico - determinação da penetração. Método de Ensaio, Rio de Janeiro, 2010a.

[15] DEPARTAMENTO NACIONAL DE INFRAESTRUTURA DE TRANSPORTES - DNIT, DNIT 131/2010 ME. Materiais asfálticos - determinação do ponto de amolecimento - Método do anel e bola. Método de Ensaio, Rio de Janeiro, 2010b.

[16] ASSOCIAÇÃO BRASILEIRA DE NORMAS TÉCNICAS - ABNT, NBR 11341: Petroleum products Determination of the flash and fire points by Cleveland open cup, Rio de Janeiro, 2004a.

[17] ASSOCIAÇÃO BRASILEIRA DE NORMAS TÉCNICAS - ABNT, NBR 15184: Bituminous materials - Viscosity determination of asphalt at elevated temperatures using a rotational viscometer, Rio de Janeiro, 2004b.

[18] ASSOCIAÇÃO BRASILEIRA DE NORMAS TÉCNICAS - ABNT, NBR 15166: Modified asphalt Test method for phase separation, Rio de Janeiro, 2004c.

[19] ASSOCIAÇÃO BRASILEIRA DE NORMAS TÉCNICAS - ABNT, NBR 15235: Asphalt materials Determination of effect of heat and air on a moving thin-film, Rio de Janeiro, 2006.

[20] DEPARTAMENTO NACIONAL DE INFRAESTRUTURA DE TRANSPORTES - DNIT, DNIT 130/2010 ME. Determinação da recuperação elástica de materiais asfálticos pelo ductilômetro. Método de Ensaio, Rio de Janeiro, 2010c.

[21] DEPARTAMENTO NACIONAL DE ESTRADAS DE RODAGEM - DNER, DNER 035/1998 ME. Agregados: Determinação da abrasão "Los Angeles". Método de Ensaio, Rio de Janeiro, 1998a.

[22] DEPARTAMENTO NACIONAL DE ESTRADAS DE RODAGEM - DNER, DNER 078/1994 ME. Agregado graúdo: adesividade a ligante betuminoso. Método de Ensaio, Rio de Janeiro, 1994a.

[23] DEPARTAMENTO NACIONAL DE ESTRADAS DE RODAGEM - DNER, DNER 086/1994 ME. Determinação do Índice de Forma. Método de Ensaio, Rio de Janeiro, 1994b.

[24] DEPARTAMENTO NACIONAL DE ESTRADAS DE RODAGEM - DNER, DNER 194/1998 ME. Agregados: Determinação da massa específica de agregados miúdos por meio do frasco Chapman. Método de Ensaio, Rio de Janeiro, 1998b.

[25] DEPARTAMENTO NACIONAL DE ESTRADAS DE RODAGEM - DNER, DNER 081/1998 ME. Agregados: Determinação da absorção e da densidade de agregado graúdo. Método de Ensaio, Rio de Janeiro, $1998 \mathrm{c}$.

[26] DEPARTAMENTO NACIONAL DE ESTRADAS DE RODAGEM - DNER, DNER 083/1998 ME. Agregados: Análise granulométrica. Método de Ensaio. Departamento Nacional de Estradas de Rodagem, Rio de Janeiro, 1998d.

[27] DEPARTAMENTO NACIONAL DE ESTRADAS DE RODAGEM - DNER, DNER 385/99 ES: Pavimentação - concreto asfáltico com asfalto polímero. Especificação de Serviço, Rio de Janeiro, 1999.

[28] DEPARTAMENTO NACIONAL DE ESTRADAS DE RODAGEM - DNER, DNER 043/1995 ME. Misturas Betuminosas a Quente - Ensaio Marshall. Método de Ensaio. Departamento Nacional de Estradas de Rodagem, Rio de Janeiro, 1995.

[29] SENÇO, W., Manual de técnicas de pavimentação, 1 ed., São Paulo, Pini, 2001. 
[30] BERNUCCI, L.B., MOTTA, L.M.G., CERATTI, J.A.P., et al., Pavimentação asfáltica: formação básica para engenheiros.1 ed., Rio de Janeiro, Petrobras: Abeda., 2008.

[31] DEPARTAMENTO NACIONAL DE INFRAESTRUTURA DE TRANSPORTES - DNIT, DNIT 136/2010 ME. Pavimentação asfáltica - Misturas asfálticas - Determinação da resistência à tração por compressão diametral. Método de ensaio. Rio de Janeiro, 2010d.

[32] DEPARTAMENTO NACIONAL DE INFRAESTRUTURA DE TRANSPORTES - DNIT, DNIT 135/2010 ME. Pavimentação asfáltica - Misturas asfálticas - Determinação do módulo de resiliência. Método de ensaio. Rio de Janeiro, 2010e.

[33] KOPPERMAN, S., TILLER, G., TSENG, M.T., Elsym5 Interactive microcomputer version: user manual ibm-pc and compatile version, FHWA, Final Report DTFH 61-85- 00051, 1985.

[34] KLAMT, R.A., "Influência da ação do tráfego no custo de construção e restauração de pavimentos asfálticos”, Thesis M.Sc, Universidade Federal de Santa Maria, Santa Maria, RS, 2014.

[35] FRANCO, F.A.C.D.P., "Um sistema para análise mecanística de pavimentos asfálticos”, Thesis M.Sc., Universidade Federal do Rio de Janeiro, Rio de Janeiro, RJ, 2000.

[36] AYRES JUNIOR, M., "Development of a rational probabilistic approach for flexible pavement analysis", Thesis D.Sc., Universatity of Maryland, College Park, EUA, 1997.

[37] PINTO, S., PREUSSLER, E.S., Pavimentação rodoviária: conceitos fundamentais sobre pavimentos flexíveis, 2ed., Rio de Janeiro, IBP, 2010.

[38] SILVA, T.O., CARVALHO, C.A.B., LIMA, D.C., et al., "Influência do tráfego de veículos comerciais em rodovias vicinais não pavimentadas: estudo de caso aplicado à VCS 346, Viçosa, MG”, Revista Árvore, v. 35, n. 3, pp. 539-545, June 2011.

[39] SILVA, T.K., CARVALHO, C.A.B., MARQUES, G.L.O., et al., "Dosagem de mistura betuminosa a frio e seu estudo sob efeitos de cargas estáticas e repetidas", Revista Árvore, v. 40, n. 1, pp. 97-107, February 2016.

[40] DEPARTAMENTO NACIONAL DE INFRAESTRUTURA DE TRANSPORTES - DNIT, DNIT 031/2006 ES. Pavimentos Flexíveis - Concreto asfáltico - Especificação de serviço, Rio de Janeiro, 2006.

\section{ORCID}

Natalia Assunção Brasil Silva

Taciano Oliveira da Silva

Heraldo Nunes Pitanga

Geraldo Luciano de Oliveira Marques https://orcid.org/0000-0002-4296-6407

https://orcid.org/0000-0003-3726-0191

https://orcid.org/0000-0001-5244-1180

https://orcid.org/0000-0003-1347-2624 